Research.

\title{
THE INFLUENCE OF FINANCIAL ATTITUDE, FINANCIAL KNOWLEDGE, AND INDIVIDUAL INCOME ON FINANCIAL MANAGEMENT BEHAVIOR OF MILLENNIAL GENERATION IN SPECIAL CAPITAL REGION OF JAKARTA
}

\author{
Ayu Rizki Nurfadillah'; Rindang Matoati ${ }^{\left.2^{*}\right)}$ \\ Department of Economics and Management, IPB University, Bogor, Indonesia \\ 1*)ayu_rizki@apps.ipb.ac.id; ${ }^{2)}$ rindang@apps.ipb.ac.id \\ * Corresponding author
}

Received: September 12, 2021 Accepted: October 12, 2021 Published: December 31, 2021

To cite this article: Nurfadillah, AR; Matoati, R. (2021). The influence of financial attitude, financial knowledge, andi individual income on financial management behavior of millennial generation in special capital region of Jakarta. The Management Journal Of Binaniaga, 6 (2), 133-150. doi:10.33062/mjb.v6i2.460

\begin{abstract}
The current era of globalization can have various impacts that can affect a person's behavior, namely financial behavior (behavior finance) in the millennial generation in Jakarta Special Capital Region. The millennial generation has a stigma that tends to be extravagant, difficult to save, has a high lifestyle, and is also consumptive, thus showing the millennial generation does not yet have good financial management behavior. This research aims to analyze the effect of financial attitudes, financial knowledge, and individual income on the financial management behavior of millennials in Jakarta Special Capital Region. The sampling technique was conducted using nonprobability sampling with purposive sampling method. The data analysis method used is SEM-PLS analysis. The results of this research indicate that financial attitudes, and financial knowledge has a positive and significant effect on the financial management behavior of the millennial generation in DKI Jakarta, and for individual income it has no significant effect on the financial management behavior of the millennial generation in DKI Jakarta
\end{abstract}

Keywords: millennial generation, income, financial knowledge, financial attitude, financial management behavior

\section{INTRODUCTION}

\section{Background}

The current era of globalization can provide many changes and impacts on society. These changes and impacts can be both positive and negative which can affect a person's behavior, one of which is financial behavior. Financial behavior can be a person's behavior in making financial decisions (Ida and Dwinta 2010). Good financial behavior can be reflected in responsible financial behavior, which can make all the finances owned can be managed properly.

Financial behavior is certainly owned by everyone, including the millennial generation. The millennial generation is a generation whose year of birth was in the early 1981 to 1996 range, this was adopted According to the results of a survey conducted by BPS in 2020 (BPS 2020) whose source of classification was According to the results of the analysis of the census Bureau population estimates. conducted by William H Frey in 2020 (Frey 2020). The millennial generation, which is included in this year's range, is a productive generation aged around 25-40 years.

The millennial generation is included in one of the generations that are still relatively difficult to manage their finances, Because of the stigma of the millennial

Ayu Rizki Nurfadillah \& Rindang Matoati. The influence of financial attitude, financial knowledge, and individual income on financial management behavior of millennial generation in special capital region of Jakarta 
generation which tends to be extravagant, difficult to save, has a high lifestyle, and is also consumptive. This is in accordance with research conducted by the IDN Research Institute in 2019 , which revealed that only $10.7 \%$ of the income generated by the millennial generation was used for savings, while the remaining $51.1 \%$ of the millennial generation's income was used for consumptive needs. and only $2 \%$ is used for investment (IDN Research Institute 2019) (Figure 1).

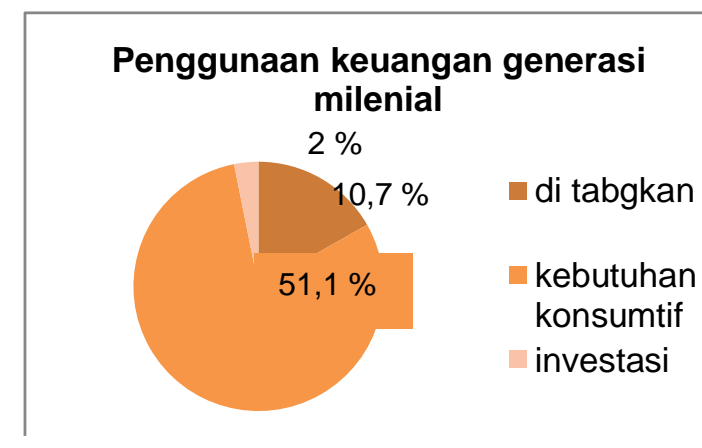

Figure 1 The use of millennial finance (IDN Research Institute 2019)

Source: IDN Research Institute Report 2019

According to other research that was released by Tirtoi in July 2019, it shows that the millennial generation tends to be more extravagant than generation $z$ or other generations, finds it difficult to save and doesn't really care about investment needs for the future (Syafina 2019). This can be caused by the characteristics of the millennial generation itself which tends to be more dynamic, creative, technologically savvy and pragmatic. There are two things that can affect the consumption pattern of the millennial generation in using their finances, namely the millennial generation's view of the terms YOLO and FOMO. YOLO stands for the principle of you only live once, this view can encourage the millennial generation to spend their income for self-fulfillment such as going to a place with very large expenses compared to setting aside some income for retirement funds, where retirement is considered too far away to think about. FOMO stands for the principle of fear of imissing out, this view can encourage the millennial generation to use money for things that are not really needed or just to follow existing trends (Dion 2020).

There are still many millennial generations in Indonesia who do not consider the importance of investing to anticipate future needs. This is in accordance with the results of the research "The Future of money" conducted by Lunoi with research agency Delia in 2019 on 7,000 respondents spread across the continents of Europe, Africa, and Southeast Asia, including Indonesia which reached $15 \%$ of the total respondents (Figure 2).

Ayu Rizki Nurfadillah \& Rindang Matoati. The influence of financial attitude, financial knowledge, and individual income on financial management behavior of millennial generation in special capital region of Jakarta 


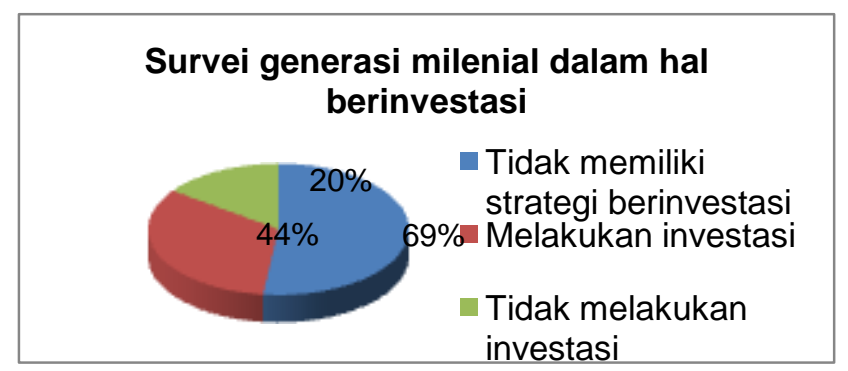

Figure 2 Survey of the millennial generation in terms of investing

\section{Source: Research results "The Future of money" in 2019}

Millennials are often said to be more consumptive than other generations. The consumptive attitude is a behavior that is no longer According to rational considerations, but because of a desire that has reached an irrational level. The consumptive attitude becomes dangerous for the millennial generation, because it can interfere with the financial management of the millennial generation itself. Consumptive life behavior can be a serious problem for the millennial generation's finances, one of which is being in debt.

The stigma of the millennial generation which is like being extravagant, difficult to save, has a high lifestyle, difficult to invest and consumptive can show that the millennial generation has not been able to manage their finances properly and correctly. It also shows that their financial management behavior is still lacking or cannot be applied properly in everyday life. The millennial generation who does not have good behavior in managing finances can make it difficult for the millennial generation to get out of the problems that often occur in managing finances.

Financial management behavior can be improved with financial attitudes and financial knowledge. Financial attitudes are also owned by a person in the form of knowledge and also the ability to do things in a certain way, namely it is the attitude that can influence a person to be able to take and make good financial decisions so that individual financial well-being can be achieved (OECD/INFE 2018). With a financial attitude that they have, of course they can help the millennial generation in making better financial decisions, because with a good financial attitude, the millennial generation already has a good mindset regarding money, can control their finances, adjust the use of money, not desire to always spend his finances, and also has a broad view of finance (Widyaningrum 2018). This is in line with research conducted by I (Herdjiono and Damanik 2016) and also (Ida and Dwinta 2010), which shows that financial attitudes have an influence on financial management behavior. But this is different from research from (Novita and Maharani 2016) which states that financial attitudes do not have a positive effect on one's financial management behavior. Meanwhile, financial knowledge is an individual's mastery or understanding of various things about the financial world (Kholilah and Iramani 2013). If the millennial generation already has good financial knowledge, the millennial generation will better understand and understand things related to money, such as understanding the basic knowledge of managing finances, financial planning, credit, insurance, various types of insurance, investment (Zenika 2015). This is in accordance with research conducted (Arifin et al. 2017), which states that financial knowledge has an influence on one's financial management behavior.

Individual income is something that can also affect the millennial generation in using their finances. According to (Ida and Dwinta 2010), there is a greater possibility that someone who already has sufficient or even excess income, will be more responsible for their financial management behavior, increasing available funds can also provide an

Ayu Rizki Nurfadillah \& Rindang Matoati. The influence of financial attitude, financial knowledge, and individual income on financial management behavior of millennial generation in special capital region of Jakarta 
opportunity to act responsibly. This is in accordance with research (Ida and Dwinta 2010), which states that individual income has a positive relationship to financial management behavior.

According to (Atkinson and Messy 2012) financial attitudes, and financial knowledge can be used to measure a person's level of financial literacy. According to the results of the OJK survey in 2019 through the results of the National Financial Literacy Survey (SNLK), it shows that the percentage of financial literacy in Indonesia is still in the low category compared to other countries in the world, which is only $38.03 \%$. This shows that the financial attitude and financial knowledge possessed by the community, including the millennial generation, is also still low, this can also cause problems for the millennial generation such as being difficult to use their money to invest, tending to be wasteful, and having high consumptive behavior.

According to the results of the Susenas conducted by BPS in 2019, it was stated that Jakarta was included in one of the provinces in Indonesia with the highest average per capita expenditure on non-food items for one DKI resident compared to four residents of East Nusa Tenggara (NTT), which was IDR 1,343,018 (BPS 2019).

The purpose of this research is to find out how the financial attitudes, financial knowledge, and individual incomes affect the millennial generation's financial management behavior in the Jakarta Special Capital Region area.

\section{Formulation of the Problems}

1. How does the financial attitude affect the financial management behavior of the millennial generation in Jakarta Special Capital Region?

2. How does financial knowledge affect the millennial generation's financial management behavior in Jakarta Special Capital Region?

3. How does the individual's income affect the financial management behavior of the millennial generation in Jakarta Special Capital Region?

\section{LITERATURE REVIEW}

\section{Financial Attitudes}

Financial attitudes include aspects that can influence a person in making financial decisions, to behave with a method (Soetiono and Setiawan 2018). If you can understand financial attitudes, it can help individuals to know something that is believed, related to an individual towards money. To form the right financial attitude, namely being able to focus on the current condition, which means that, I do not think about the past and worry about the future (Widyaningrum 2018).

\section{Financial Knowledge}

Financial knowledge is an ability to manage finances, which is useful for improving the welfare of individual lives (Ameliawati and Setiyani 2018). There is an assumption that a person who has a good education can increase his knowledge in various fields, including in finance which will have an impact on making more effective financial decisions (Sandi et al. 2020). Financial knowledge (Halim and Astuti 2015) is that the better the financial knowledge you understand, the better your financial skills in financial management will be.

\section{Individual Income}

Income is a source of revenue for someone who is obtained through business activities, services, or can be through gifts from other people (parents), which is expected

Ayu Rizki Nurfadillah \& Rindang Matoati. The influence of financial attitude, financial knowledge, and individual income on financial management behavior of millennial generation in special capital region of Jakarta 
to have a maximum value at the beginning of the period equal to the maximum value at the end of the period which can be used to fulfill living standards (Prihartono and Asandimitra 2018). Individual income includes compensation from a number of sources, namely salaries, wages, and bonuses obtained from work or self-employment, dividends and distributions received from investments, rental receipts from real estate investments, or profit sharing from businesses (Kagan 2021).

\section{Financial Management Behavior}

Financial management behavior is the acquisition, allocation, and use of financial resources that are goal-oriented (Topa et al. 2018). Financial management behavior is someone's ability to manage, namely planning, budgeting, checking, managing, controlling, finding and storing daily financial funds (Kholilah and Iramani 2013).

\section{RESEARCH METHODS}

This research is a part of quantitative research. The data sources used in this research are primary and secondary sources (Abdillah and Hartono 2015). The primary sources used are through the distribution of online questionnaires distributed to the millennial generation in Jakarta Special Capital Region, while the secondary sources are through relevant literature from various sources, such as reputable journals, scientific articles, literature studies, books and so on.

The population of this research is the millennial generation who live in the Jakarta Special Capital Region area. The number of samples in this research were 177 respondents. For the method of determining the sample in this research, the noni probability sampling method (random or intentional noni sampling) with purposive sampling technique was used. The data analysis technique used is descriptive analysis and analysis using SEM-PLS. In this research, there are three independent variables and one independent variable. The first independent variable is financial attitude, which can be measured by 5 indicators (Widyaningrum 2018), namely:

1. Show a good mindset about money

2. Be able to control the financial situation you have

3. Adjust the use of money to your needs

4. Don't want to spend money

5. Have a broad view of money

The second independent variable is financial knowledge, which can be measured by 8 indicators (Zenika 2015), namely:

1. Knowledge of financial management

2. Knowledge of financial planning

3. Knowledge of expenses and income

4. Knowledge of credit

5. Basic knowledge of insurance

6. Knowledge of various types of insurance

7. Basic knowledge of investment

8. Knowledge of investment in property

The third independent variable is individual income, measured by a categorical scale consisting of 5 categories (Dwei 2017), as follows:

1. Less than 3 million (<IDR $3,000,000)$

2. 3 million to 5 million (IDR $3,000,001-$ IDR $5,000,000$ )

3. 5 million up to 7 million (IDR $5,000,001-$ IDR $7,000,000$ )

4. 7 million to 9 million (IDR $7,000,001$ - IDR $9,000,000$ )

5. More than 9 million (> IDR $9,000,000$ )

Ayu Rizki Nurfadillah \& Rindang Matoati. The influence of financial attitude, financial knowledge, and individual income on financial management behavior of millennial generation in special capital region of Jakarta 
The dependent variable in this research is financial management behavior, which can be measured by 5 indicators (Zenika A 2015):

1. Types of financial planning and budgeting

2. Saving activities

3. Insurance, pension, and unexpected expenses

4. Investment activities, credit or debt, and bills

5. Financial management evaluation

\section{RESULTS AND DISCUSSION}

Characteristics of respondents in this research include gender, age, last education, employment status, and also domicile. For gender characteristics, female respondents were dominated by $53.1 \%$ with 94 respondents, and $46.9 \%$ male respondents with 83 respondents. For age characteristics, this research is dominated by the millennial generation aged $25-28$ years, which is $66.1 \%$ with a total of 117 respondents. In addition, the characteristics of the latest education and employment status are dominated by the millennial generation who took the last education, namely the undergraduate level of $\mathrm{S} 1$ by $63.3 \%$, and dominated by private employees and also employees of BUMN by $50.3 \%$ and $22.6 \%$, respectively. For domicile characteristics, dominated by the millennial generation who live in the West Jakarta area.

The financial attitude of the millennial generation in Jakarta Special Capital Region

The average financial attitude of the millennial generation in Jakarta Special Capital Region is 3.39. This shows that the financial attitude of the millennial generation in Jakarta Special Capital Region is classified as excellent.

Tabel 1 Analisis deskriptif variabel sikap keuangan

\begin{tabular}{lcccccccc}
\hline \multicolumn{1}{c}{ Indicators } & \multicolumn{2}{c}{$\begin{array}{c}\text { Frequency of } \\
\text { respondents' } \\
\text { answers }\end{array}$} & & $\begin{array}{c}\text { Mean } \\
\text { indicator }\end{array}$ & Criteria & $\begin{array}{c}\text { Mean } \\
\text { variable }\end{array}$ & Criteria \\
& 1 & 2 & 3 & 4 & & & & \\
\hline $\begin{array}{l}\text { Show a good mindset } \\
\text { about money (SK1) }\end{array}$ & 2 & 2 & 60 & 107 & 3.47 & excellent & & \\
$\begin{array}{l}\text { Able to control the } \\
\text { financial situation }\end{array}$ & 5 & 11 & 68 & 93 & 3.41 & excellent & & \\
$\begin{array}{l}\text { owned (SK2) } \\
\begin{array}{l}\text { Adjusting the use of } \\
\text { money to needs (SK3) }\end{array}\end{array}$ & 6 & 15 & 58 & 98 & 3.40 & excellent & 3.39 & excellent \\
$\begin{array}{l}\text { Don't want to spend } \\
\text { money (SK4) }\end{array}$ & 3 & 14 & 82 & 78 & 3.33 & excellent & & \\
$\begin{array}{l}\text { Have a broad view of } \\
\text { money (SK5) }\end{array}$ & 3 & 8 & 91 & 75 & 3.34 & excellent & & \\
\hline
\end{tabular}

According to table 1, the highest value is found in the first indicator (SK1), namely, showing a good mindset about money at 3.47 and classified as very good criteria, this shows that the millennial generation in Jakarta has a good mindset about money which is can support the financial attitude of the millennial generation to be able to help make good financial decisions in order to improve their financial management behavior. This is followed by the second indicator (SK2), namely, being able to control their financial situation, which is 3.41 and classified as very good criteria, this shows that the millennial generation in Jakarta tends to be able to control their financial situation. In addition, the millennial generation has also been able to adjust their financial use to fulfill

Ayu Rizki Nurfadillah \& Rindang Matoati. The influence of financial attitude, financial knowledge, and individual income on financial management behavior of millennial generation in special capital region of Jakarta 
their needs (SK3), which shows a value of 3.40 , which means that the millennial generation can use their finances according to their needs. Having a broad view of money (SK5) also has a value of 3.34, and the lowest value is found in the indicator (SK4), which is not willing to spend money, with a value of 3.33 , this shows that the millennial generation still spends more financially immediately compared to be stored for future use.

\section{Millennial generation financial knowledge in Jakarta Special Capital Region}

The average financial knowledge of the millennial generation in Jakarta Special Capital Region is 3.30. This shows that the financial knowledge possessed by the millennial generation in Jakarta Special Capital Region is classified as excellent.

Table 2. Descriptive analysis of financial knowledge variables

\begin{tabular}{|c|c|c|c|c|c|c|c|c|}
\hline \multirow[t]{2}{*}{ Indicators } & \multicolumn{4}{|c|}{$\begin{array}{l}\text { Frequency of } \\
\text { respondents' } \\
\text { answers }\end{array}$} & \multirow[t]{2}{*}{$\begin{array}{l}\text { Mean } \\
\text { indicator }\end{array}$} & \multirow[t]{2}{*}{ Criteria } & \multirow[t]{2}{*}{$\begin{array}{c}\text { Mean } \\
\text { variable }\end{array}$} & \multirow[t]{2}{*}{ Criteria } \\
\hline & 1 & 2 & 3 & 4 & & & & \\
\hline $\begin{array}{l}\text { Financial Management } \\
\text { Knowledge (PK1) }\end{array}$ & 1 & 15 & 90 & 71 & 3.31 & Excellent & & \\
\hline $\begin{array}{l}\text { Financial Management } \\
\text { Knowledge (PK2) }\end{array}$ & 3 & 23 & 87 & 64 & 3.20 & good & & \\
\hline $\begin{array}{l}\text { Knowledge of } \\
\text { Expenses and Income } \\
\text { (PK3) }\end{array}$ & 2 & 3 & 70 & 102 & 3.54 & excellent & & \\
\hline $\begin{array}{l}\text { Knowledge of Credit } \\
\text { (PK4) } \\
\text { Basic Knowledge of }\end{array}$ & 3 & 3 & 80 & 91 & 3.46 & excellent & 3.30 & excellent \\
\hline $\begin{array}{l}\text { Insurance (PK5) } \\
\text { Knowledge of Various }\end{array}$ & 7 & 41 & 73 & 56 & 3.01 & Good & & \\
\hline $\begin{array}{l}\text { Types of Insurance } \\
\text { (PK6) }\end{array}$ & 11 & 25 & 88 & 53 & 3.03 & good & & \\
\hline $\begin{array}{l}\text { Basic Knowledge of } \\
\text { Investment (PK7) }\end{array}$ & 2 & 6 & 68 & 101 & 3.51 & excellent & & \\
\hline $\begin{array}{l}\text { Knowledge } \\
\text { Investing in Property } \\
\text { (PK8) }\end{array}$ & 2 & 24 & 62 & 89 & 3.34 & excellent & & \\
\hline
\end{tabular}

According to table 2, the highest value is found in the third indicator (PK3), namely, knowledge of income and expenditure of 3.54 which is included in the very good criteria, where the millennial generation in Jakarta Special Capital Region has been able to manage their expenditures and also their financial income so that expenditure and income can be controlled properly. This is followed by the seventh indicator (PK7), namely, basic knowledge about investment of 3.51, which shows that the millennial generation in Jakarta Special Capital Region already has good knowledge regarding investment and can use this related knowledge to allocate their finances for useful activities. In addition, the millennial generation in Jakarta Special Capital Region also has

Ayu Rizki Nurfadillah \& Rindang Matoati. The influence of financial attitude, financial knowledge, and individual income on financial management behavior of millennial generation in special capital region of Jakarta 
very good knowledge regarding knowledge about credit (PK4), concerning investment in property (PK8), and related to financial management (PK1), which have values of 3.46 , 3.34, and 3.31. The millennial generation in Jakarta Special Capital Region has knowledge related to financial planning (PK2), and related to various types of insurance (PK6) which are classified as good, the values show 3.20 and 3.03. The lowest value is found in the fifth indicator (PK5), namely, basic knowledge related to insurance which has a value of 3.01, this shows that there are still many millennials in Jakarta Special Capital Region who do not really understand insurance. the value shows 3.20 and 3.03 . The lowest value is found in the fifth indicator (PK5), namely, basic knowledge related to insurance which has a value of 3.01 , this shows that there are still many millennials in Jakarta Special Capital Region who do not really understand insurance. the value shows 3.20 and 3.03. The lowest value is found in the fifth indicator (PK5), namely, basic knowledge related to insurance which has a value of 3.01 , this shows that there are still many millennials in Jakarta Special Capital Region who do not really understand insurance.

\section{Millennial generation individual income in Jakarta Special Capital Region}

The average individual income of the millennial generation in Jakarta Special Capital Region is 2.49. This shows that the individual income of the millennial generation in Jakarta Special Capital Region is poor.

Tabel 2 Analisis deskriptif variabel pendapatan individu

\begin{tabular}{|c|c|c|c|c|c|c|c|}
\hline \multirow[t]{2}{*}{ Indicators } & \multicolumn{3}{|c|}{$\begin{array}{l}\text { Frequency of } \\
\text { respondents' } \\
\text { answers }\end{array}$} & \multirow[b]{2}{*}{4} & \multirow[b]{2}{*}{5} & \multirow[t]{2}{*}{$\begin{array}{c}\text { Mean } \\
\text { variable }\end{array}$} & \multirow[t]{2}{*}{ Criteria } \\
\hline & 1 & 2 & 3 & & & & \\
\hline$<$ IDR 3,000,000 & 29 & & & & & & \\
\hline $\begin{array}{l}\text { IDR 3,000,001 - } \\
\text { IDR 5,000,000 }\end{array}$ & & 80 & & & & & \\
\hline $\begin{array}{l}\text { IDR } 5,000,001- \\
\text { IDR } 7,000,000\end{array}$ & & & 40 & & & 2.49 & Poor \\
\hline $\begin{array}{l}\text { IDR } 7,000,001- \\
\text { IDR } 9,000,000\end{array}$ & & & & 8 & & & \\
\hline$>$ IDR $9,000,000$ & & & & & 20 & & \\
\hline
\end{tabular}

According to table 3 , the most respondents in this research have individual incomes in the income range of IDR 3,000,001 - IDR 5,000,000, namely 80 respondents, followed by respondents who have individual incomes in the income range of IDR $5,000,001$ - IDR $7,000,000$ as many as 40 people, in the third place are respondents who have an individual income of < IDR 3,000,000 which is as many as 29 people, in fourth place are respondents who have an individual income > IDR 9,000,000 which is as many as 20 people, and in the last order are respondents who have individual income in the income range of IDR $7,000,001$ - IDR $9,000,000$ which is only 8 people.

\section{The financial management behavior of the millennial generation in Jakarta Special Capital Region}

The average financial management behavior of the millennial generation in Jakarta Special Capital Region is 3.35. This shows that the financial management behavior of the millennial generation in Jakarta Special Capital Region is classified as excellent.

Table 4. Descriptive analysis of financial management behavior variables

Ayu Rizki Nurfadillah \& Rindang Matoati. The influence of financial attitude, financial knowledge, and individual income on financial management behavior of millennial generation in special capital region of Jakarta 


\begin{tabular}{|c|c|c|c|c|c|c|c|c|}
\hline \multirow[t]{2}{*}{ Indicators } & \multicolumn{4}{|c|}{$\begin{array}{l}\text { Frequency of } \\
\text { respondents' } \\
\text { answers }\end{array}$} & \multirow[t]{2}{*}{$\begin{array}{c}\text { Mean } \\
\text { indicator }\end{array}$} & \multirow[t]{2}{*}{ Criteria } & \multirow[t]{2}{*}{$\begin{array}{l}\text { Mean } \\
\text { variable }\end{array}$} & \multirow[t]{2}{*}{ Criteria } \\
\hline & 1 & 2 & 3 & 4 & & & & \\
\hline $\begin{array}{l}\text { Types of financial } \\
\text { planning and budgeting } \\
\text { (PMK1) }\end{array}$ & 4 & 12 & 76 & 85 & 3.37 & excellent & & \\
\hline Saving activity (PMK2) & 3 & 27 & 77 & 70 & 3.21 & good & & \\
\hline $\begin{array}{l}\text { Insurance activities, and } \\
\text { unexpected expenses } \\
\text { (PMK3) }\end{array}$ & 2 & 13 & 76 & 86 & 3.39 & excellent & 3.35 & excellent \\
\hline $\begin{array}{l}\text { Investment activities, } \\
\text { credit, bills (PMK4) }\end{array}$ & 3 & 4 & 69 & 101 & 3.51 & excellent & & \\
\hline $\begin{array}{l}\text { Financial management } \\
\text { evaluation (PMK5) }\end{array}$ & 5 & 15 & 84 & 73 & 3.27 & excellent & & \\
\hline
\end{tabular}

According to table 4, the highest value is found in the fourth indicator (PMK4), namely, behavior in conducting investment, credit, billing activities with a value of 3.51 which is included in the very good criteria, millennials in Jakarta have good behavior in using their finances, especially in investing activities, meeting billing needs, and also activities in using credit. This is followed by the third indicator (PMK3), namely, related to insurance activities, and unexpected expenses, with a value of 3.39 , where the millennial generation already has financial management behavior that is classified as good in terms of insurance activities, and sets aside or manages finances for expenses. unexpected. In addition, the millennial generation in Jakarta Special Capital Region also has excellent financial management behavior related to the types of financial planning and budgeting (PMK1) they have, financial management evaluation (PMK5) which has a value of 3.37 and 3.27. The lowest value is found in the second indicator (PMK2), namely, financial management behavior in saving activities which has a value of 3.21, this shows that the millennial generation in Jakarta Special Capital Region is still lacking in showing financial management behavior in terms of saving.

\section{Results of SEM-PLS Analysis}

\section{Evaluation of Measurement Model (outer model)}

The evaluation of this measurement model is used to find out how the manifest variables can be measured and evaluate the validity and reliability of the indicators used on the latent variables.

\section{Validity Test}

\section{a) Convergent Validity}

Convergent validity can be used to measure how big the indicators are in explaining the latent variables. An indicator can be said to be valid for measuring a construct if it has a loading factor value greater than 0.70 but a loading factor value greater than 0.50 to 0.60 is still acceptable in research (Ghozali 2014). In this research, the reference condition for the loading factor value is greater than 0.60 (Ghozali 2014).

The initial model of this research, which is before dropping can be seen in Figure 3

Ayu Rizki Nurfadillah \& Rindang Matoati. The influence of financial attitude, financial knowledge, and individual income on financial management behavior of millennial generation in special capital region of Jakarta 


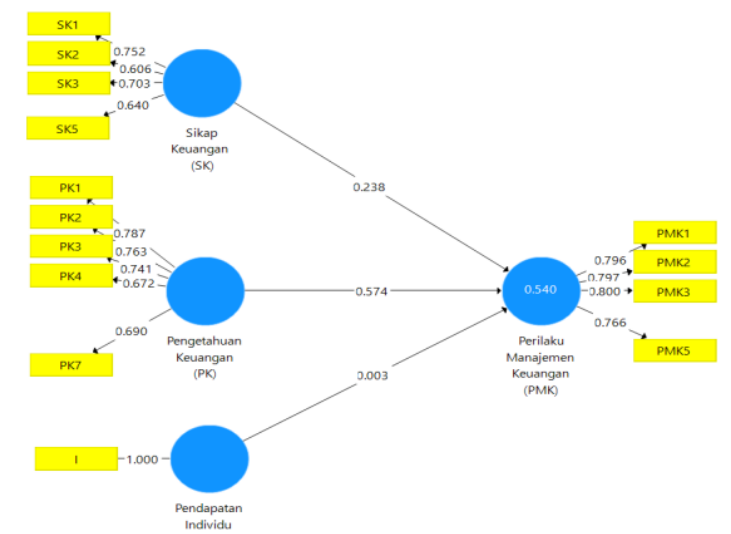

Picture 3 Outer model before dropping

Source: Primary data (Processed data in 2021)

The results of the Outer initial model show that there are five indicators that have a loading factor value of less than 0.60 , so that the indicator must be dropped. These indicators are not willing to spend money (SK4), basic knowledge of insurance (PK5), knowledge of various types of insurance (PK6), knowledge of investment in property (PK8), and investment, credit and billing activities (PMK4). The results of the outer model after dropping can be seen in Figure 4

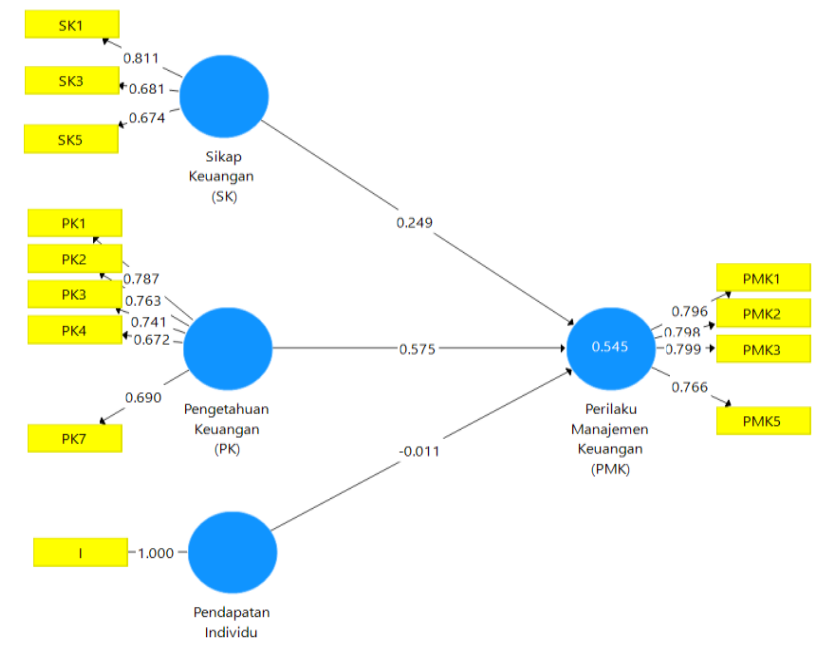

Figure 4 Outer model after dropping

Source: Primary data (Processed data in 2021)

After dropping for the first time, the AVE value of the financial attitude variable has a value that is still less than the specified conditions, which is less than 0.50 , to produce even better data, the financial attitude indicator can be dropped again, namely for indicators capable of controlling financial situation. owned (SK2), so that the results of the outer model after dropping the second time can be seen in Figure 5

Ayu Rizki Nurfadillah \& Rindang Matoati. The influence of financial attitude, financial knowledge, and individual income on financial management behavior of millennial generation in special capital region of Jakarta 


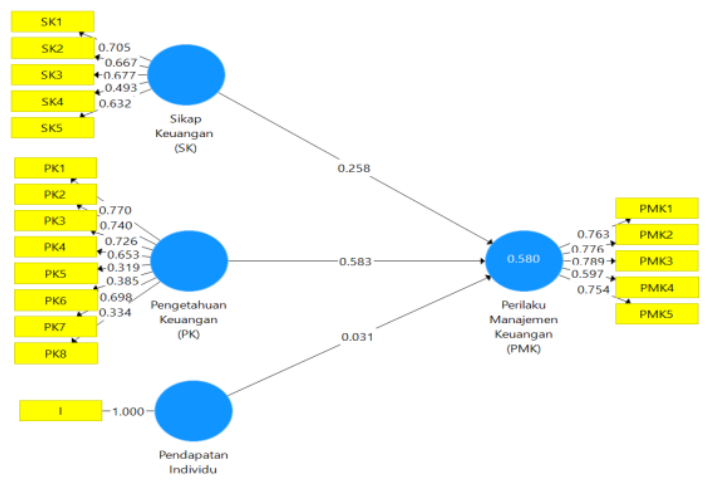

Figure 5 Outer model after the second dropping

Source: Primary data (Processed data in 2021)

There are 13 other indicators that have met the requirements for a loading factor value of more than 0.60 , so dropping does not have to be done, and can show that the validity of the research model can be declared good.

In Figure 5, it can be seen that the financial attitude variable has 3 main indicators, namely, showing a good mindset about money (SK1), adjusting the use of money to needs (SK3), and having a broad view of money (SK5). In the financial attitude variable, the indicator shows a good mindset about money that can reflect the financial attitude variable, with the largest loading factor value among other indicators, which is 0.811. Respondents indicated that with indicators showing a good mindset about money can improve their financial management behavior. The financial knowledge variable has 5 main indicators, namely, knowledge of financial management (PK1), knowledge of financial planning (PK2), knowledge of financial expenditure and income (PK3), knowledge of credit (PK4), and basic knowledge of investment (PK7). In the financial knowledge variable, the financial management knowledge indicator can reflect the financial knowledge variable, with the largest loading factor value among other indicators, which is 0.787 . Respondents indicated that the indicators of financial management knowledge can improve their financial management behavior.

Furthermore, in the evaluation using the convergence validity test, it can also be seen by looking at the Average Variance Extracted (AVE) value of the construct used. The required AVE value is greater than 0.50. For more details can be seen in Table 5

Table 5 AVE Value

\begin{tabular}{lc}
\hline \multicolumn{1}{c}{ Variabel laten } & Nilai AVE \\
\hline Financial Attitude & 0.525 \\
Financial Knowledge & 0.536 \\
Individual Income & 1.000 \\
Financial Management & 0.624 \\
Behavior & \\
Source: Primary data (Processed data in 2021)
\end{tabular}

According to Table 5 , it shows that the AVE value for each construct in this research has met the requirements, which is greater than 0.50 . This value means that the variance that can be captured by the construct is greater than the variance generated by measurement error, so the model can be said to be good.

b) Discriminant validity

Ayu Rizki Nurfadillah \& Rindang Matoati. The influence of financial attitude, financial knowledge, and individual income on financial management behavior of millennial generation in special capital region of Jakarta 
Evaluation of discriminant validity can be seen from the cross-loading value generated. Discriminant validity can be said to have good results, if it can explain the indicators in one latent variable have a greater value than the indicator value for other latent variables. The value of cross loading can be seen in Table 6 .

Table 6 Cross-loading Value

\begin{tabular}{|r|c|c|c|c|}
\hline & $\begin{array}{c}\text { Financial } \\
\text { Attitude (SK) }\end{array}$ & $\begin{array}{c}\text { Financial Knowledge } \\
(\mathrm{PK})\end{array}$ & $\begin{array}{c}\text { Individual } \\
\text { Income (I) }\end{array}$ & $\begin{array}{c}\text { Financial Management } \\
\text { Behavior (PMK) }\end{array}$ \\
\hline SK1 & $\mathbf{0 . 8 1 1}$ & 0.413 & 0.164 & 0.480 \\
\hline SK3 & $\mathbf{0 . 6 8 1}$ & 0.392 & -0.092 & 0.357 \\
\hline SK5 & $\mathbf{0 . 6 7 4}$ & 0.356 & 0.047 & 0.334 \\
\hline PK1 & 0.471 & $\mathbf{0 . 7 8 7}$ & 0.007 & 0.535 \\
\hline PK2 & 0.416 & $\mathbf{0 . 7 6 3}$ & 0.039 & 0.560 \\
\hline PK3 & 0.362 & $\mathbf{0 . 7 4 1}$ & 0.005 & 0.493 \\
\hline PK4 & 0.322 & $\mathbf{0 . 6 7 2}$ & -0.013 & 0.458 \\
\hline PK7 & 0.371 & $\mathbf{0 . 6 9 0}$ & 0.044 & 0.533 \\
\hline I & 0.069 & 0.024 & $\mathbf{1 . 0 0 0}$ & 0.020 \\
\hline PMK1 & 0.433 & 0.596 & 0.001 & $\mathbf{0 . 7 9 6}$ \\
\hline PMK2 & 0.441 & 0.557 & 0.037 & $\mathbf{0 . 7 9 8}$ \\
\hline PMK3 & 0.441 & 0.549 & 0.077 & $\mathbf{0 . 7 9 9}$ \\
\hline PMK5 & 0.439 & 0.531 & -0.052 & $\mathbf{0 . 7 6 6}$ \\
\hline
\end{tabular}

Source: Primary data (Processed data in 2021)

According to the table 6 , the cross-loading value shows that the indicator value in one latent variable already has a greater correlation with the cross-loading value in other latent variables. This shows that the placement of indicators on each latent variable used is correct, and each indicator on the latent variable has been able to predict its own variable compared to other indicators in the other latent variables.

\section{Reliability Test}

The reliability of the construct can be seen through the composite reliability value. Composite reliability is rated better in estimating the internal consistency of a construct (Salisbury et al. 2002). The composite reliability value must be greater than 0.70 (Hair and et al 2014). The composite reliability value of this research can be seen in Table 7.

Table 7 Results of Composite Reability

\begin{tabular}{|l|c|}
\hline \multicolumn{1}{|c|}{ Latent Variable } & $\begin{array}{c}\text { Composite } \\
\text { reability }\end{array}$ \\
\hline Financial Attitude & 0.767 \\
\hline Financial Knowledge & 0.852 \\
\hline Individual Income & 1.000 \\
\hline $\begin{array}{l}\text { Financial Management } \\
\text { Behavior }\end{array}$ & 0.859 \\
\hline
\end{tabular}

Source: Primary data (Processed data in 2021)

According to the resulting composite reliability value, it shows that all composite reliability values in the latent variable have a value greater than 0.70 , so that these variables can be reliable and are considered to have good reliability.

Ayu Rizki Nurfadillah \& Rindang Matoati. The influence of financial attitude, financial knowledge, and individual income on financial management behavior of millennial generation in special capital region of Jakarta 


\section{Evaluation of the Structural Model (Inner Model)}

The structural model or inner model in SEM-PLS is evaluated by looking at the value of R-square (R2) for the dependent latent variable, and the resulting path coefficient value. The value of $R$-squarei(R2) is useful for measuring the level of variation in changes in the independent variable to the dependent variable (Abdilah and Hartono 2015). Path coefficient value by looking at the t-statistics value of each path to test the significance between constructs in the structural model. The t-statistics value used to determine the significance test is with a 95 percent confidence interval with a t-table value of 1.96. For the value of R-square (R2) can be seen in table 8 below:

Table 8 Value of $\mathrm{R}$ - square (R2)

\begin{tabular}{|l|c|}
\hline \multicolumn{1}{|c|}{ Latent Variable } & $R$-square $\left(R^{2}\right)$ \\
\hline $\begin{array}{l}\text { Financial management } \\
\text { behavior (PMK) }\end{array}$ & 0.545 \\
\hline
\end{tabular}

Source: Primary data (Processed data in 2021)

The value of $\mathrm{R}$-square (R2) obtained is 0.545 or $54.5 \%$, which variable can be explained by the financial attitude variable, financial knowledge and also individual income of $54.5 \%$, and the rest can be explained by other variables outside the model described above. submitted. After the measurement model can reflect the latent variables used, it can do bootstrapping to find out the results of hypothesis testing. Evaluation of the structural model is used to see the influence between the latent variables used, namely through the estimation of the path coefficient value and the level of significance. In testing with bootstrapping, it is possible to determine the effect and also the hypothetical model that is made can be accepted or rejected. Bootstrapping results on the evaluation of the structural model (Figure 6).

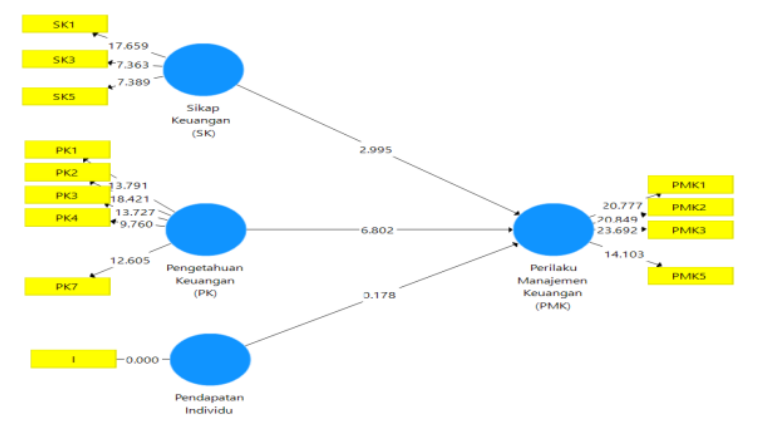

Figure 6 Bootstrapping results on the structural model

Source: Primary data (Processed data in 2021)

Figure 6 explains that the value of the path coefficient can show significance in hypothesis testing. The value of the path coefficient must have a t-statistic value greater than the t-table value with a $5 \%$ alpha significance level of 1.96 . To find out the effect test, it can be seen from the value of t-table with t-statistics, which if the value of $t$ statistics is greater than t-table (1.96), then the research hypothesis can be accepted, but if the value of t-statistics is smaller from the t-table (1.96), then the research hypothesis is rejected. The following is the result of the path coefficient (Table 9).

Ayu Rizki Nurfadillah \& Rindang Matoati. The influence of financial attitude, financial knowledge, and individual income on financial management behavior of millennial generation in special capital region of Jakarta 
Table 9 Path coefficient results

\begin{tabular}{|l|c|c|c|c|c|c|}
\hline $\begin{array}{l}\text { Relationship } \\
\text { between latent } \\
\text { variables }\end{array}$ & $\begin{array}{l}\text { Original } \\
\text { sample }\end{array}$ & $\begin{array}{c}\text { Sample } \\
\text { Mean (M) }\end{array}$ & $\begin{array}{c}\text { Standard } \\
\text { Deviation } \\
\text { (STDEV) }\end{array}$ & $\begin{array}{c}\text { T-Statistics } \\
(\text { (O/STERR/) }\end{array}$ & Influence & Hypothesis \\
\hline $\begin{array}{l}\text { Financial } \\
\text { attitude -> } \\
\text { Financial } \\
\text { management } \\
\text { behavior }\end{array}$ & 0.249 & 0.257 & 0.083 & 2.995 & $\begin{array}{c}\text { Positive } \\
\text { influence, and } \\
\text { significant }\end{array}$ & Accepted \\
\hline $\begin{array}{l}\text { Financial } \\
\text { knowledge -> } \\
\text { Financial } \\
\text { management } \\
\text { behavior }\end{array}$ & 0.575 & 0.576 & 0.085 & 6.802 & $\begin{array}{c}\text { Positive } \\
\text { influence, and } \\
\text { significant }\end{array}$ & Accepted \\
\hline $\begin{array}{l}\text { Individual } \\
\text { income } \\
\text { Financial } \\
\text { management } \\
\text { behavior }\end{array}$ & -0.011 & -0.010 & 0.062 & 0.178 & $\begin{array}{c}\text { No influence, } \\
\text { and not } \\
\text { significant }\end{array}$ & Rejected \\
\hline
\end{tabular}

(Source: Primary data (Processed data in 2021)

According to the results in Table 9, several conclusions can be drawn from the influence of financial attitudes, financial knowledge, and individual income on the financial management behavior of millennials in Jakarta Special Capital Region, which are as follows:

\section{The Influence of Financial Attitude on Financial Management Behavior}

Financial attitude has a significant effect on financial management behavior with a $\mathrm{t}$-statistic value of 2,995 and the original sample value of 0.249 . The $\mathrm{t}$-statistic value which shows $>1.96$, it can be said that the first hypothesis is acceptable. According to this, it can be explained that there is a significant and positive relationship between the financial attitude variable and the financial management behavior variable.

Financial attitudes can influence the millennial generation in Jakarta Special Capital Region in determining their financial management behavior. In this case, it states that the better the financial attitude they have, the better the millennial generation will be in making various decisions related to their financial management, they will also experience fewer difficulties in managing finances compared to the millennial generation who do not have a good financial attitude, because they already understand a good attitude in managing their finances. Millennials who have a good financial attitude can also show a good mindset related to money, such as being able to manage money well for now and also for the future, being able to control their financial situation, being able to adjust the use of money to their needs, do not want to spend money directly, and certainly have a broad view of money. The results of this research are in line with the research conducted by (Mien and Thao 2015) which states that there is a positive influence and has a significant relationship between the two.

\section{The Influence of Financial Knowledge on Financial Management Behavior}

Financial knowledge has a significant effect on financial management behavior with a $\mathrm{t}$-statistic value of 6.802 and the original sample value of 0.575 . The $\mathrm{t}$-statistic value which shows $>1.96$, it can be said that the second hypothesis can be accepted. According to this, it can be explained that there is a significant and positive relationship between the financial knowledge variable and the financial management behavior variable.

Ayu Rizki Nurfadillah \& Rindang Matoati. The influence of financial attitude, financial knowledge, and individual income on financial management behavior of millennial generation in special capital region of Jakarta 
Financial knowledge can influence the millennial generation in Jakarta Special Capital Region in determining their financial management behavior. In this case, it is proven that the millennial generation who has good financial knowledge, they can manage their finances properly and correctly, because with high knowledge related to finance, someone already knows and understands related knowledge in financial management, knowledge of financial planning, knowledge of expenses and income, knowledge of credit, insurance, investment, which of these things can be some of the factors that make the millennial generation able to manage their finances better. In addition, with good financial knowledge, millennials can make the millennial generation better at using money, and can also provide benefits to their lives. The results of this research are in line with research conducted by (Anggraeni and Tandika 2019) and (Arifin and Siswanto 2017), which state that financial knowledge has a significant influence on financial management behavior.

\section{The Influence of Individual Income on Financial Management Behavior}

Personal income has no effect on financial management behavior with a t-statistic value of 0.178 and the original sample value of -0.011 . The t-statistic value shows $<1.96$, it can be said that the third hypothesis is rejected. According to this, it shows that there is no significant effect and also shows a negative relationship from the individual income variable to the financial management behavior variable.

In this research, the most dominant millennial generation are those with incomes between IDR 3,000,000 - IDR 5,000,000, namely 80 people, in second place are those with incomes between IDR 5,000,001 - IDR 7,000,000, namely 40 people, in the order of third, namely those with incomes less than IDR 3,000,000, namely 29 people, in the fourth place, namely those with incomes more than IDR $9,000,000$, namely as many as 20 people, and in the last order, namely those with incomes between IDR 7,000,001 IDR $9,000,000$, namely as many as 8 people.

This states that, someone who has the largest income, which is > IDR $9,000,000$ does not affect the millennial in improving his financial management behavior, this can be caused by several factors, such as external factors, namely from the environment, where the millennial generation has income. high, of course the surrounding environment can also affect them in using their finances. The next factor is from internal factors, where it comes from the millennial generation itself, which still does not show good financial management behavior. In addition, for the millennial generation who have moderate to middle income, they also have not used it well so they still have financial management behavior that is still lacking.

This is not in line with research conducted by (Novianti 2019) which states that individual income has a relationship and has a positive effect on financial management behavior, they state that someone who has a better income can manage finances well too. However, the results of this research are in accordance with research conducted by (Ida and Dwinta 2010), which states that individual income does not have an influence on financial management behavior, which states that someone who has better personal income may not necessarily be able to manage his personal finances well too.

\section{CONCLUSIONS AND SUGGESTIONS}

\section{Conclusion}

According to this research, several conclusions were obtained, namely as follows:

1. Characteristics of respondents in this research, namely the millennial generation, which is dominated by women, aged $25-28$ years. The last education is dominated by bachelor degree. The work status of the millennial generation is dominated by private employees and also BUMN employees. Meanwhile, the Jakarta Special Capital Region area is dominated by the millennial generation who live in the West Jakarta area.

Ayu Rizki Nurfadillah \& Rindang Matoati. The influence of financial attitude, financial knowledge, and individual income on financial management behavior of millennial generation in special capital region of Jakarta 
2. According to the results of the hypothesis test, the result that the financial attitude variable has a positive and significant influence on the financial management behavior of the millennial generation in Jakarta Special Capital Region.

3. According to the results of the hypothesis test, the result that the financial knowledge variable has a positive and significant influence on the financial management behavior of millennials in Jakarta Special Capital Region.

4. According to the results of the hypothesis test, the result that the individual income variable has no influence and is not significant on the financial management behavior of the millennial generation in Jakarta Special Capital Region.

\section{Suggestion}

According to the results of this research, there are several suggestions that can be used as input, including:

1. The Financial Services Authority (OJK) in disseminating education to the millennial generation who have worked in private companies and in state-owned companies, can disseminate the education at least 1 time in 1 year, or it can be done regularly every 6 months which can be done online.

2. For further research, other variables other than individual income can be used. When using individual income variables, you can use the same measurement scale as the other variable measurement scales, in order to produce even better results.

3. For further research, it can be done in other regions or areas not only in the Jakarta Special Capital Region area which has different respondent characteristics, both demographic, psychographic, and sociocultural characteristics, in order to get a broader picture to obtain better data processing results.

\section{REFERENCES}

Abdillah DrW, Hartono J. (2015). Partial Least Square (PLS), Alternatif Structural Equation Modeling (SEM) dalam Penelitian Bisnis. C.V Andi

Ameliawati M, Setiyani R. (2018). The Influence of Financial Attitude, Financial Socialization, and Financial Experience to Financial Management Behavior with Financial Literacy as the Mediation Variable. KSS. 3(10):811. https://doi:10.18502/kss.v3i10.3174.

Anggraeni AA, Tandika D. (2019). Pengaruh Financial Literacy dan Financial Attitude terhadap Financial Management Behavior. Prosiding Manajemen. 5(1).

Atkinson A, Messy FA. (2012). "Measuring Financial Literacy". Journal of Consumer Affairs. 44(02):296-316. https://doi:10.1111/j.1745- 6606.2010.01170.x.

Biro Pusat Statistik. (2019). Pengeluaran untuk konsumsi penduduk Indonesia per provinsi (consumption expenditure of population of Indonesia by province). ( $3^{\text {rd }} \mathrm{ed}$ ) BPS-Statistics Indonesia.

Biro Pusat Statistik. (2020). Hasil Sensus Penduduk 2020. https://www.bps.go.id

Ayu Rizki Nurfadillah \& Rindang Matoati. The influence of financial attitude, financial knowledge, and individual income on financial management behavior of millennial generation in special capital region of Jakarta 
Dion. (2020). Generation Gap: Gaya pengelolaan Keuangan Milenial dan Gen Z. http://avrist.com/lifeguide/pengelolaan-keuangan-milenial-dan-gen-z-generation-gap/.

Frey WH. (2020). Analysis of census bureau population estimates. http://www.freydemographer.org/

Ghozali I. (2014). Structural Equation Modeling, Metode Alternatif dengan Partial Least Square (PLS). ( $4^{\text {th }}$ ed). Badan Penerbit Universitas Diponegoro.

Hair JF, et al, editor. (2014). Multivariate Data Analysis. ( $7^{\text {th }}$ ed)., Pearson new internat. ed. Harlow: Pearson.

Halim YKE, Astuti D. (2015). Financial Stressors, Financial Behavior, Risk Tolerance, Financial Solvency, Financial Knowledge, dan Kepuasan Finansial. FINESTA. Vol. 3(No. 1):19-23.

Ida, Dwinta CY. (2010). Pengaruh Locus of Control, Financial Knowledge, Income Terhadap Financial Management Behavior. Jurnal Bisnis dan Akuntansi. 12(3):131144.

IDN Research Institue. (2019). Indonesia Millenial Report 2019: Memahami Perilaku Milenial Indonesia. https//www.idntimes.com

Kagan J. (2021). Personal Income. https://www.investopedia.com/terms/p/personalincome.asp

Kholilah NA, Iramani Rr. (2013). Studi Financial Management Behavior Pada Masyarakat Surabaya. JBB. 3(1):69. https//doi:10.14414/jbb.v3i1.255.

Mien NTN, Thao TP. (2015). Factors Affecting Personal Financial Management Behaviors: Evidence from Vietnam. :16.

Novianti S. (2019). Pengaruh Locus Of Control, Financial Knowledge, Income Terhadap $\begin{array}{llll}\text { Financial Management } & \text { Behavior. }\end{array}$ https//doi:10.35446/akuntansikompetif.v2i1.278.

Organization of Economic Co-Operation and Development/International Network on Financial Inclusion. (2018). Organization of Economic Co-Operation and Development/International Network on Financial Inclusion. https://www.oecd.org

Prihartono MRD, Asandimitra N. (2018). Analysis Factors Influencing Financial Management Behaviour. International Journal of Academic Research in Business and Social Sciences. 8(8):308-326.

Salisbury D, et al. (2002). Research Report: Better Theory Through MeasurementDeveloping a Scale to Capture Consensus on Appropriation. Information System Research. Vol 13(No. 1). https://doi.org/10.1287/isre.13.1.91.93.

Sandi K, et al. (2020). Pengaruh Financial Knowledge Dan Financial Attitude Terhadap Financial Behavior Pada Youth Entrepreneur Kota Malang. Profit : Jurnal Administrasi Bisnis.(Special Issues (Ekosistem StarUp):11.

Ayu Rizki Nurfadillah \& Rindang Matoati. The influence of financial attitude, financial knowledge, and individual income on financial management behavior of millennial generation in special capital region of Jakarta 
The Management Journal of BINANIAGA Vol. 06, No.02, December 2021

p-ISSN: $2527-4317$, e-ISSN: $2580-149 x$

$6^{\text {th }}$ Accreditation Rating: April 04, $2019-$ April 03, 2024

Soetiono KusumaningtutiS, Setiawan C. (2018). Literasi dan Inklusi Keuangan Indonesia. $\left(1^{\text {st }}\right.$ ed) Rajawali Pers.

Syafina DC. (2019). Mengapa generasi milenial sulit mengelola keuangan. https://tirto.id/mengapa-generasi-milenial-sulit-mengelola-keuangan-eeDV

Topa G, et al. (2018). Financial Management Behavior Among Young Adults: The Role of Need for Cognitive Closure in a Three-Wave Moderated Mediation Model. Front. Psychol. 9:2419. https://doi:10.3389/fpsyg.2018.02419.

Ayu Rizki Nurfadillah \& Rindang Matoati. The influence of financial attitude, financial knowledge, and individual income on financial management behavior of millennial generation in special capital region of Jakarta 